OPEN ACCESS

Edited by:

Robyn Wilson,

The Ohio State University,

United States

Reviewed by:

Arjan Wardekker,

University of Bergen, Norway

James C. Arnott,

Aspen Global Change Institute,

United States

${ }^{*}$ Correspondence:

Erin Upton

eupton@pdx.edu

Specialty section:

This article was submitted to

Climate Risk Management,

a section of the journa

Frontiers in Climate

Received: 18 January 2021

Accepted: 11 May 2021

Published: 07 June 2021

Citation:

Upton E and Nielsen-Pincus M (2021)

Climate Change and Water

Governance: Decision Making for Individual Vineyard Owners in Global Wine Regions. Front. Clim. 3:654953.

doi: 10.3389/fclim.2021.654953

\section{Climate Change and Water Governance: Decision Making for Individual Vineyard Owners in Global Wine Regions}

\author{
Erin Upton* and Max Nielsen-Pincus \\ Department of Environmental Science and Management, Portland State University, Portland, OR, United States
}

This study investigates the institutional, social, and ecological dynamics that influence regional water governance and individual vineyard owners' decision making in global wine regions. Global wine grape production has grown steadily over the past 20 years, and climate change has emerged as a driver of transformation in wine regions resulting in a range of impacts. Changes to the climate are anticipated to accelerate in the future and present a number of challenges for wine regions; including risks to human systems, e.g., agriculture, labor, and economics, as well as ecological systems, e.g., surface and groundwater. Water is a critical resource for environmental and economic sustainability in wine regions, and vulnerability to freshwater resources in wine producing regions is expected to increase as wine regions experience climate extremes like heat and drought. We use the Institutional-Social-Ecological Dynamics (ISED) framework to help understand individual vineyard owner decision making about water management within the context of institutional, social, and ecological systems. We ask how the relationships between these systems impact outcomes for individual grape farmers adapting to climate challenges. Our empirical research uses document review and interviews with vineyard owners, planners, and natural resource managers in wine regions in Oregon, USA and Tasmania, Australia as a means to explore climate vulnerabilities and adaptation approaches. Subsequently we focus on an example vignette in each region to better understand individual decision making at the farm scale within the unique institutional, social, and ecological contexts identified in each region. Our cases highlight the finding that entrenched institutional regimes, in the context of ecological variability contribute to a social unevenness in access to water. Landowner conflict over water resources is likely to increase in the context of a hotter, drier climate in regions with wine industry growth. Individual vineyard owners have a range of attitudes and approaches to climate change planning and management; and adaptation around water is dependent on both economic resources and social values. Lessons from the individual farm scale help to inform broader implications of how institutional, social, and ecological drivers influence opportunities or barriers to the implementation of climate change adaptation practices in wine regions.

Keywords: climate change adaptation, water governance, decision making, wine regions, resilience 


\section{INTRODUCTION}

Wine regions exist on nearly every continent. Global wine grape production has grown steadily over the past 20 years (OIV, 2019). During the same time period global climate change has emerged as a driver of transformation in wine regions resulting in a range of impacts (Jones et al., 2005). Changes to the climate are anticipated to accelerate in the future and present a number of challenges for the wine industry and wine region communities (see Table 1). Agriculture worldwide will be affected by rising temperatures and increases in extreme weather events, and these changes in climate will impact where grapes can be grown in the future (Tate, 2001; Furer, 2006; Hannah et al., 2013). Individual grape varieties are grown within narrow climate ranges for optimum quality and production, which puts wine grapes at greater risk than other crops to short-term climate variability and long-term climate changes (Jones and Webb, 2010). Shifts in temperature patterns globally may also cause grape growing to move out of areas where it currently exists, and shift into regions that become newly suitable with climate change (Porter et al., 2014). Some estimates have found that by 2100 the United States could lose $>80$ percent of its premium wine grape acreage (Kay, 2006).

Climate change presents risks to human systems, like agriculture, labor, and economics, as well as ecological systems, like surface and groundwater (Jimenez Cisneros et al., 2014; Porter et al., 2014). Water is a critical resource for environmental and economic sustainability in wine regions. Climate change can result in vulnerability to freshwater resources in wine producing regions, where water demand is anticipated to increase with more frequent climate extremes like heat and drought (Jones et al., 2005; Deitch et al., 2009; Forbes et al., 2013; Conradie et al., 2014). The wine industry relies on access to freshwater resources and it is predicted that climate change will result in an overall decrease in the availability of freshwater in wine regions (Tate, 2001; Ecos, 2013). Water is used in the vineyards for farming the wine grape crops, which can include irrigation; spraying pesticides, herbicides and fungicides; and overhead irrigation for mitigation of extreme climate events like frost and excessive heat (Quiggin et al., 2010). Water is used in the cellar operations during the winemaking and bottling processes, and in hospitality facilities for visitors. Water use is a growing concern, particularly in regions experiencing drought (Comandaru et al., 2012; Conradie et al., 2014).

Current climate adaptation research in wine focuses predominantly on viticulture science, new technologies in farming, and modeling future climate scenarios in grape growing regions (Jones et al., 2005; Hannah et al., 2013; Mozell and Thach, 2014). The wine industry puts into practice a variety of adaptation strategies to cope with climate challenges, both technological and operational. Water governance, which encompasses policy, planning, and management decisions around water resources, influences innovation, adoption, and choice in climate adaptation efforts. The influence of institutions on the adoption of new science and technologies is currently under investigated in the wine industry. The process and outcomes of water governance need to be better understood to ensure future ecological and economic sustainability for

TABLE 1 | Climate change impacts and wine region vulnerabilities.

\begin{tabular}{|c|c|c|}
\hline Climate change impacts & Wine region vulnerabilities & Citations \\
\hline $\begin{array}{l}\text { Changes to the traditional historic } \\
\text { growing season in a wine region }\end{array}$ & $\begin{array}{l}\text { - Earlier bud break-increased susceptibility to frost, hail } \\
\text { - Earlier harvests-labor and operations challenges, high temperatures } \\
\text { - Compression of harvests-impacting operations, availability of labor, capacity in } \\
\text { the winery-availability of fermentation tanks, presses, etc. }\end{array}$ & $\begin{array}{l}\text { Jones et al., 2005; Hadarits } \\
\text { et al., 2010; Hannah et al., } 2013\end{array}$ \\
\hline Uncertainty of future climate & $\begin{array}{l}\text { - Lack of knowledge when selecting new plantings (grape variety, rootstock, } \\
\text { clone) } \\
\text { - Uncertainty of future water needs } \\
\text { - Expansion of vineyard plantings into previously undeveloped areas-loss of } \\
\text { habitat, biodiversity }\end{array}$ & $\begin{array}{l}\text { Hadarits et al., 2010; Hannah } \\
\text { et al., 2013; Mozell and Thach, } \\
2014\end{array}$ \\
\hline Extreme Heat & $\begin{array}{l}\text { - Heat stress to vine health } \\
\text { - Damage to grape crop } \\
\text { - Risk to human health-farmworkers } \\
\text { - Increased need for water }\end{array}$ & $\begin{array}{l}\text { Jones et al., 2005; Hannah et al., } \\
2013\end{array}$ \\
\hline Drought & $\begin{array}{l}\text { - Drought stress to vine health, compounded over multiple growing seasons } \\
\text { - Increased competition for or unavailability of scarce water resources }\end{array}$ & $\begin{array}{l}\text { Jones et al., 2005; Hannah et al., } \\
2013\end{array}$ \\
\hline $\begin{array}{l}\text { Highly variable or extreme weather } \\
\text { events }\end{array}$ & - Damage to grape crop-heat, rain, hail, frost, etc. & $\begin{array}{l}\text { Hadarits et al., 2010; Hannah } \\
\text { et al., 2013; Mozell and Thach, } \\
2014\end{array}$ \\
\hline $\begin{array}{l}\text { Increased rainfall during the growing } \\
\text { season }\end{array}$ & $\begin{array}{l}\text { - Damage to grape crop-mold, mildew, pests, etc. } \\
\text { - Increase use of pesticides and fungicides-costs and environmental impacts }\end{array}$ & $\begin{array}{l}\text { Jones et al., 2005; Mozell and } \\
\text { Thach, } 2014\end{array}$ \\
\hline Warmer winter temperatures & $\begin{array}{l}\text { - Damage to grapevines-wood rot, pests } \\
\text { - Increase use of pesticides and fungicides-costs and environmental impacts }\end{array}$ & Jones et al., 2005 \\
\hline $\begin{array}{l}\text { Increase in frequency or severity of } \\
\text { bush/forest fires }\end{array}$ & $\begin{array}{l}\text { - Damage to grape crop-smoke taint } \\
\text { - Risk to human health and property }\end{array}$ & Belliveau et al., 2006 \\
\hline
\end{tabular}




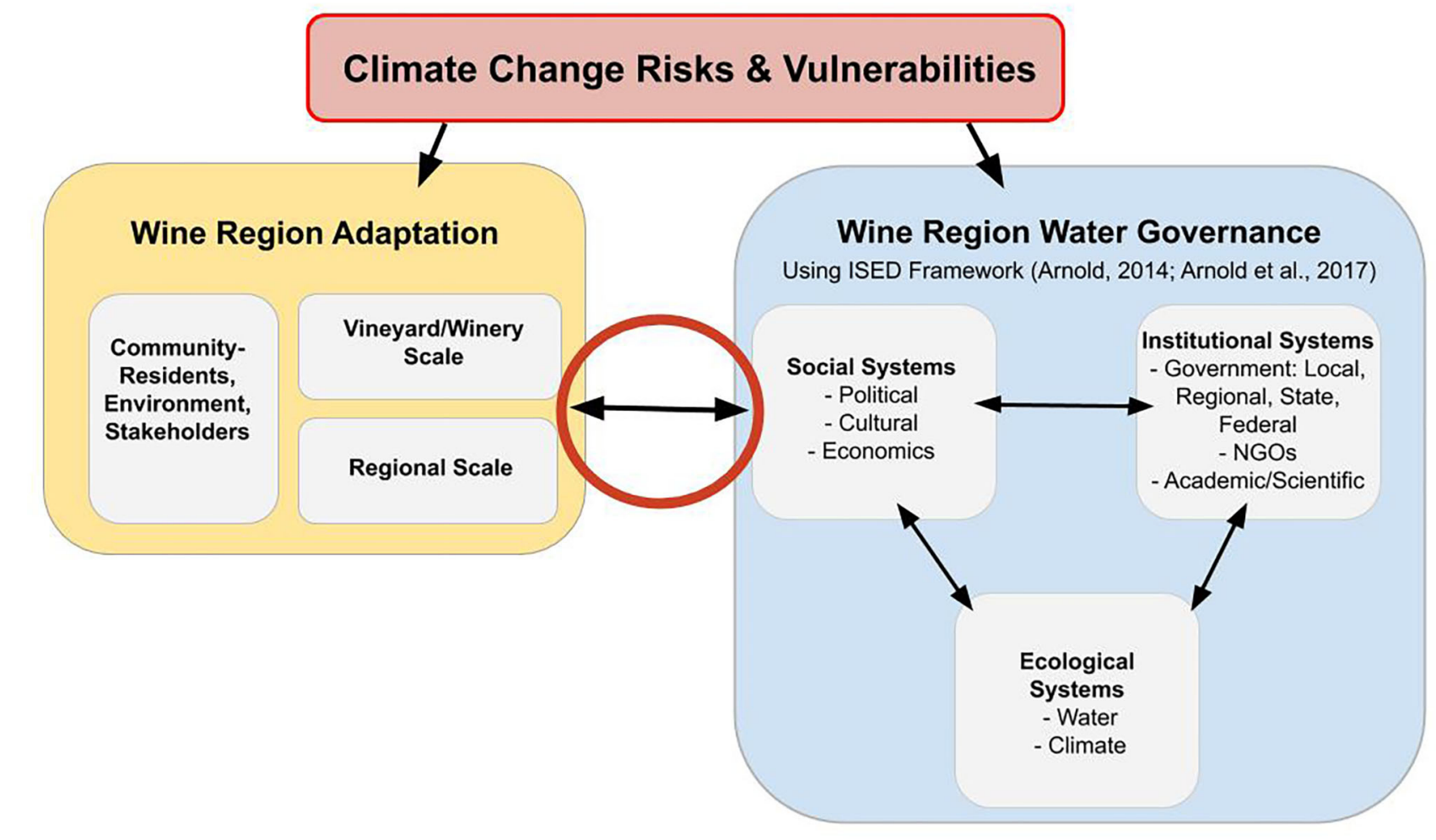

FIGURE 1 | Conceptual diagram using ISED framework approach-the relationship between wine region adaptation to climate change risks and vulnerabilities and water governance. Examples of institutional, social, and ecological systems as identified in the case studies.

individual farmers in wine regions, and to increase resiliency to future climate uncertainties (see Figure 1). To address this need, our research uses the Institutional-Social-Ecological Dynamics (ISED) framework (Arnold, 2014; Arnold et al., 2017). ISED builds on the social-ecological systems (SES) concept where humans are part of nature and our history of delineating or separating them is artificial (Berkes et al., 2008). One benefit of considering the interconnectivity of these different and intricate systems is that we can begin to better understand complexity (Ascough Ii et al., 2008; Berkes et al., 2008). SES are made up of both biophysical and social factors that regularly interact, and these factors form systems that exist at several spatial, temporal, and organizational scales (Holling and Gunderson, 2002; Redman et al., 2004). ISED was developed to explicitly recognize the strong role of institutions in SES. In our use of the ISED framework, ecological systems include the physical (e.g., climate and soils) and biological (e.g., vegetation) systems that influence water resource availability across the landscape, and social systems include cultural, political, and economic drivers. Institutional systems are defined as the prescriptions people use to organize interactions at all scales. Institutions are made up of rules, norms, and cultural beliefs which contribute to shaping social actions. Institutions include both formal and informal governance systems, decentralized and collaborative systems of collective action, and legal regimes, including legislation, regulation, and enforcement. Climate adaptation in the wine industry can be approached from a number of disciplines, but there is the opportunity to examine the intersection between science and governance (Hannah et al., 2013). The wine industry exists within the context of regional communities where water resources are shared by stakeholders with varied and sometimes conflicting needs (Ostrom, 2009; Lange and Shepheard, 2014). A deeper understanding of the influences of social and institutional systems in climate adaptation is needed for potential solutions to be sustainable (Lereboullet et al., 2013). Our research adds to the broader climate change discourse in wine industry research by going beyond viticulture and technological solutions; filling a gap in existing knowledge by examining relationships among institutional, social, and ecological systems. This examination contributes to better understanding around decision making about climate adaptation options related to water resources in these regions.

\section{MATERIALS AND METHODS \\ Qualitative Inquiry and Comparative Case Studies}

We used a qualitative approach to explore complex issues that need to be understood in context, vs. relying solely on 
predetermined information found in the literature (Denzin and Lincoln, 2011). We conducted a comparative case study in 2018-2019 between two wine regions, the Willamette Valley in Oregon, USA and Tasmania, Australia, in order to examine how water governance creates opportunities or barriers to climate change adaptation in wine regions. To begin, we developed focused research questions and an interview guide based on themes found in data from 47 semi-structured, exploratory interviews we conducted in wine regions in North America, South Africa, and Australia in 2016. The exploratory research included interviews with wine industry professionals, academic researchers, government agency employees, water managers, land use planners, and environmental conservationists (Upton and Nielsen-Pincus, 2020).

\section{Case Selection}

The criteria for the selection of case study wine regions was a combination of similarities and differences in regions, as well as familiarity and access. The Willamette Valley and Tasmanian wine regions share similarities, despite their great distance from one another. Both regions are considered cooler climate growing regions and they produce the same varieties of grapes, predominantly Pinot noir, Pinot gris, Riesling, and Chardonnay. The wine industries in both regions have reputations for high quality grapes and wine production. Only small amounts of wines are produced in these regions, and the wines sell for premium prices. Both regions have been experiencing growth, and are located in geographic proximity to large, well-established wine grape growing regions-California and the mainland of Australia - that are currently experiencing serious challenges with heat, drought, and wildfires (Jones and Webb, 2010; Harris et al., 2019; Upton and Nielsen-Pincus, 2020). Tasmania and Oregon have not experienced extensive climate change related outcomes yet, but this is beginning to shift. In both regions, water belongs to the public, but access, management, and oversight is controlled by the state. The regions are different in the historical and current practices of water governance, including the history of water rights, the use of irrigation, the use of surface water vs. groundwater, and the development of water markets.

\section{Case Study Areas \\ Willamette Valley, Oregon}

Oregon is the third largest wine grape producing region in the United States, with 20 sub-American Viticulture Areas (AVA). The Oregon wine industry has grown considerably in the last two decades, from 139 wineries in 2000 to nearly 800 wineries in 2018, although the majority of producers are small, making $<5,000$ cases of wine annually (Oregon Wine Board, 2019). The Willamette Valley region has $\sim 70$ percent of the vineyards in Oregon with over 24,000 acres of planted vineyards and nearly 600 wineries (Willamette Valley Wineries Association, 2020). One economic driver in wine regions is agritourism. In order to sell wine directly to consumers, the wine industry promotes tourism in rural regions, with tasting rooms, special events, and visitor accommodations. These types of activities can cause conflict with rural residential neighbors and other farm operations, including fears of exacerbating water scarcity issues with increased demand (Upton and Nielsen-Pincus, 2020). Along with overall wine industry growth in the region, there is a trend toward consolidation within the industry, with larger companies from outside the region buying and building wineries and vineyards in the Willamette Valley. The larger companies often have more substantial financial resources. This growth in the wine industry is combined with shifting practices that potentially use more water, like irrigation, increased yields of grape and wine production, and an increase in tourism activities. These changes are taking place in the context of a region that has a growing demand for water resources from a range of stakeholders, and a projected climate future of increased water scarcity. In the coming decades, water demand is anticipated to increase with projected population growth, an upsurge of development, expansion of agricultural irrigation, and the need for environmental flows, i.e., leaving water in rivers and streams as habitat for fish, including federally-listed threatened and endangered species (Jaeger et al., 2013).

The Willamette Valley historically has had a temperate climate with wet winters and dry summers, but Oregon is already feeling the impacts of climate change. The current observed climate shows that Oregon continues to warm in all seasons. The Pacific Northwest region of the U.S. has warmed by $1.1^{\circ} \mathrm{C}$ since 1900. The years 2016-2019 were warmer than the 1970-1999 average. Climate models show the future climate in Oregon will continue to warm by $2.2-4.9^{\circ} \mathrm{C}$ by 2100 depending on global emissions rise (Mote et al., 2019). Annual precipitation in Oregon is not projected to change in terms of amount, but models suggest modest decreases in summer precipitation and increases in winter precipitation. Extreme and heavy rain events could increase by 10 percent in western Oregon by mid-century. Mountain snowpack is a natural reservoir for water in Oregon. Melting snow in the spring and summer seasons supplies surface water flow and recharges groundwater aquifers (Mote et al., 2019). Snowpack is predicted to decline significantly in winter months; instead precipitation will fall as rain and rapid runoff will occur in the winter, contributing to flood risks. Lack of snowpack storage will lead to water scarcity in warmer months (Mote et al., 2019). A joint research project between scientists at a number of Oregon universities used downscaled local climate models to project future water conditions in the Willamette Basin through 2100. The results of their study aligned with other findings about temperature and precipitation. They found that for every $1.6^{\circ} \mathrm{C}$ increase in annual mean temperature, there will be a roughly $15 \%$ decrease in summer flow in the lower Willamette River Basin (Jaeger et al., 2013). In addition, fire risk is projected to increase across the entire state, with large increases in the Willamette Valley (Mote et al., 2019).

\section{Tasmania, Australia}

Tasmania is a very small region, producing $<0.5$ percent of Australia's national wine grape production, although Tasmania has been experiencing strong growth and vineyard expansion in recent years (Winetitles, 2010). The growth of the industry from 2013 to 2017 resulted in 25 percent more vineyard plantings (Wine Tasmania, 2020). Increased consumer demand for cool climate grape varieties like Pinot noir and a growing awareness 
of Tasmanian wines have positioned the region as a premium wine producer. Values of Tasmanian wine grapes are at least four times the national average, with bottles retailing over 30 Australian dollars (Winemakers Federation of Australia, 2013). While the majority of mainland wine producers have had issues with oversupply and declines in returns on investment in exports in recent years, Tasmanian wine has had returns 2.5 times higher than the Australian average (Lewis et al., 2015). Most producers in Tasmania sell their wine through cellar doors (tasting rooms) and directly to restaurants. A small number of wineries sell to the mainland, and even fewer export internationally. The state of Tasmania is legally classified as one region for geographical origin indication purposes. The wine sub-regions on the island are concentrated in the central and eastern areas with less rugged terrain than the west (Lewis et al., 2015). The wine sector attracted nearly 250,000 visitors to its cellar doors in 2016, $\sim 20$ percent of all of the island's visitors. Along with vineyard and winery expansion, there has been growth in new business in packaging, bottling, restaurants, and tourism infrastructure (Wine Tasmania, 2020).

All areas of Australia are experiencing hotter than average temperatures, hotter summers with longer heatwaves, changes in the intensity of rainfall, and more frequent bushfires (Lereboullet et al., 2013). The projections show that climate change is going to become progressively more significant than natural variability in weather, with strong warming trends that accelerate toward the end of the century (Harris et al., 2019). In 2010, the Antarctic Climate and Ecosystems Cooperative Research Centre (ACE CRC) at the University of Tasmania modeled climate futures for the island, providing fine-scale climate projections using downscaled climate models based on a high greenhouse gas (GHG) emissions scenario and a low emissions scenario. Climate information was generated from 1961 to 2100 . The historical data shows that the average temperature in Tasmania has increased by more than $0.5^{\circ} \mathrm{C}$ since 1950 , and this was typically an increase in nighttime temperatures. By 2100, temperatures are projected to increase by $1.6-2.9^{\circ} \mathrm{C}$ depending on GHG emissions levels. The highest temperatures are likely to happen in the northeast and interior of the island. Heat waves and multiple days with high temperatures are projected to increase. Spring and autumn months have large projected increases $>4^{\circ} \mathrm{C}$ (Bennett et al., 2010). Heatwaves are anticipated to occur four times more frequently than current conditions (White et al., 2009). Bushfires are a historic and current occurrence in Tasmania, and according to an ACE CRC report, it is expected that fire danger will roughly double over twice the area of land by the end of the century (Fox-Hughes et al., 2015). Frequency and severity of extreme weather events is anticipated to increase, with the intensity of rainfall heightening flood risk. Coastal communities will experience more frequent storm surges and sea level rise (Antarctic Climate Ecosystems Cooperative Research Centre, 2010). While there is not a prediction for less rainfall on the island with future climate scenarios, there will be differences in intensity and timing which can increase uncertainty about water reliability for summer irrigation. Drought projections and water supply are concerns in the region. With shifts in when rain events occur, there can be challenges around negative impacts to crops with
TABLE 2 | Table of key knowledge holder interview participants.

\begin{tabular}{lcc}
\hline Key knowledge holders & Tasmania & Willamette Valley \\
\hline $\begin{array}{l}\text { Wine industry-winery and } \\
\text { vineyard owners, winemakers, } \\
\text { viticulturists, marketing }\end{array}$ & 11 & 14 \\
representatives & 6 & 3 \\
$\begin{array}{l}\text { Academic researchers } \\
\text { Professionals or government }\end{array}$ & 10 & 10 \\
$\begin{array}{l}\text { agency representatives-planning, } \\
\text { climate change, water resource } \\
\text { management, environmental }\end{array}$ & & \\
$\begin{array}{l}\text { conservation } \\
\text { Total-52 }\end{array}$ & & 25 \\
\hline
\end{tabular}

the new arrival of summer rains. Disease pressure from summer precipitation is ranked as a high risk in the wetter regions (Harris et al., 2019). In a wine region historically known for a short growing season, where it can be challenging to fully ripen the grape crop in a cool year, there is some hope that warming trends will have a positive impact with a potential for a longer growing season (Harris et al., 2019). On the other hand, grape growers express concern about warmer winter temperatures resulting in earlier bud-break on the vines, making them more susceptible to spring frost.

\section{Data Collection in Case Study Areas}

We conducted 52 interviews with key knowledge holders, 27 in Tasmania and 25 in the Willamette Valley. The participants were a sample representative of regional stakeholders, who provided narratives, perceptions, and insights from a broad range of perspectives, including: the wine industry, government staff from natural resource management agencies, and academic and conservation institutions (see Table 2). Participants were selected through a process of targeted outreach and snowball sampling, where interview participants provide names of other contacts who could be useful in understanding particular subjects (Atkinson and Flint, 2004). Wine industry participants included a range of roles but also scale and type of business. The interviews were arranged ahead of time by email and participants were provided with the interview guide in advance. The interview guide consisted of high-level questions around eight major themes. The first theme focused on water management in each region and included probes around stakeholders and users, season and annual variability in water quantity, water quality, and perceptions of vulnerability of the region's water management systems to climate change. The second theme focused on water access and use with probes around water sources, water rights, water uses. The third theme focused in more depth around stakeholders in water resources management, including key agencies, institutions, and industries involved in decision making as well as who was missing. The fourth and fifth themes focuses on conflict and cooperation around water resource management. The sixth, seventh, and eighth themes focused on production of and access to information about water resources in the context of climate change, political will to address climate 
related vulnerabilities, and plausible longer-term outcomes for water governance and wine production. Although the interview guide for all respondents asked mainly identical questions, the interviews were semi-structured, so the guide served as a starting point, allowing tailoring to the specifics of the interviewee, and follow-up questions to follow new and different thematic paths. Interviews ranged from $30 \mathrm{~min}$ to $2 \mathrm{~h}$, with most lasting $\sim 1 \mathrm{~h}$. All protocols were reviewed and approved by the Portland State University Institutional Review Board (Protocol \#184553).

In addition, we reviewed legislation, policy, planning, and management documents related to water resources, agriculture, and climate change in order to best understand the components, structures, influences, and outcomes of governance in each region. We approached this from a range of governance scales including local, regional, state, national, and global. We selected documents referenced in peer-reviewed literature, found on institutional websites, or identified by interview participants. In addition, we reviewed publicly available meeting minutes as well as popular news articles related to the research themes regarding wine industry growth, government-business enterprise, and climate change, among others. In total we reviewed 65 sources of archival material.

\section{Thematic Analysis}

We used thematic analysis to move beyond description of the data to interpretation, in an attempt to theorize significance in the patterns in the data that became themes, and the relationships between and across themes (Braun and Clarke, 2006). We transcribed each interview and used Atlas.ti software to assign codes (themes) to segments of text in each transcript. We began with a total of 22 deductive codes, which came directly from the interview guide (see Appendix 1). Following this, we developed 42 sub-themes that were inductive, emergent, and nested beneath the "parent" set of codes, for example, the parent code "Water" has seven sub-themes: "water as an economic good," "water access," "water rights," "attitudes and perceptions," "water quality," "water quantity," and "other environmental considerations." We used the ISED framework to organize the coded data into institutional, social, and ecological categories. General results are presented first as analytic narratives of the institutional, social, and ecological dynamics of each study area that go beyond thematic descriptions to interpretations of significance and meaning in the findings (Patton, 1990). Subsequently we present an example vignette in each study area of individual vineyard owners to better understand decision making at the individual farm scale within these unique institutional, social, and ecological contexts using the themes identified across each region. Finally, we present an analysis of the barriers and opportunities and make recommendations for climate adaptation in wine region water governance that engages both case studies.

\section{RESULTS}

\section{Willamette Valley, Oregon, U.S.A.}

In Oregon, institutional constraints on water use form the boundaries within which climate adaptation occurs. A number of state agencies are responsible for managing water, but two agencies are predominantly in charge of water quality and quantity. The Oregon Water Resources Department (OWRD) is responsible for administering water access and use through water rights, licenses, and permits, while the Department of Environmental Quality (DEQ) Water Resources Division is responsible for water quality standards. Authority for OWRD and DEQ Water Resources Division are derived from different pieces of state legislation, and according to a representative from one of the agencies:

"Water quality and water quantity do not speak to each other much, because DEQ is not allowed to take into (account) the quantity aspect of water when they do their quality reviews."

Nonetheless, even though they are managed separately, water quality is directly related to water quantity, mainly because low streamflow concentrates pollutants. According to DEQ's Water Resources Division, dissolved oxygen and algal growth, resulting from interactions between agricultural runoff, water temperatures, and other factors, are two of the most common water quality issues in the state. Groundwater quality is at risk from contaminants from agriculture. The DEQ Water Resources Division states that the Willamette Basin contains some of the state's most challenging water quality issues; in their most recent basin assessment agricultural land use is the largest source of pollution in the most disturbed streams (DEQ, 2009).

In addition to the fragmentation of water governance authority, Oregon, and many other jurisdictions in the western US and elsewhere, follow the doctrine of Prior Appropriation as a major means of determining water access. Prior appropriation is a legal framework with two main tenets: (1) beneficial use, which is the basis, measure, and limit of all rights to the use of the water, and (2) priority-diversion, which establishes priority dates for appurtenant uses (Oregon Water Resources Department, 2018), also known as "first-in-time/first-in-right." The water right holder with the earliest priority date at a specific location is the senior user, while more recent water right holders are junior users. In the event that water use is restricted, senior users may use the full amount allowed, while junior users are restricted. Fragmented governance and adherence to prior appropriation were two major institutional dynamics that form a foundation upon which current decision making about water management and climate adaptation occur.

These dynamics mean that vineyard access to water is determined by geographical location. In areas with available groundwater, vineyards may want to circumvent these surface water rights dynamics through use of groundwater. Groundwater, however, is not a panacea and necessitates a groundwater right permit. According to one water consultant who frequently works with wine industry clients:

"What people are doing is applying for new ground water rights. Surface water is generally not available for new uses during the irrigation season... if they're wanting to do a winery, a tasting room, then they're getting a groundwater right." 
However, many of the Willamette Valley wine grape growing areas have basalt aquifers with very little available water. One vineyard owner in the Ribbon Ridge AVA drilled 11 separate wells on his property without successfully finding a reliable source of water. A Willamette Valley Viticulturist shared:

\begin{abstract}
"They put in... a bunch of reservoirs and they started sucking the water out of the ground. And the neighbors complained that their wells started going dry. She says they don't really use groundwater. It's mostly surface water. So I don't really know the truth there, but that is the perception."
\end{abstract}

Market institutions are relatively scarce in the Willamette Valley wine growing region, but in a few areas, vineyard owners can buy water from an irrigation district.

Despite a general perception that Oregon has wet weather, the challenges with institutional access to water led the majority of interview participants in the wine industry, academics, politicians, water consultants, water lawyers, and resource agency employees to observe this social dynamic as a misconception about the abundance of water in western Oregon. A number of wine industry participants shared that the reality of obtaining a water right was not as straightforward as they would have anticipated. Many participants had concerns about the growing demand for water. Population growth in the Willamette Valley means municipalities are also working to secure access to drinking water that will meet current and future demands. Some in the agriculture sector are concerned about the ability to access adequate amounts of water in the future; while others who hold senior water rights express fears about losing access to water should current laws be restructured. A viticulturist shared his perspective on water access in the Willamette Valley:

\footnotetext{
"It seems like everybody is scared. Water rights are getting more difficult. Or there is more regulation... what I find is there is not availability of information. So you don't know. You don't know how to get a permit (or) what is right and what is wrong."
}

A winemaker and grape grower who has participated in a number of industry technical committees over the years explained that he has given talks to his peers in the wine industry, emphasizing that water could be a limited resource for the future of their industry and urging them to begin to address the issue now before it is too late. He expressed difficulty in getting people to care. There is a divergence of attitudes within the wine industry; for many it doesn't feel like a pressing issue yet, and for others it is a critical issue that should not be overlooked.

Another concern raised by interview participants in Oregon is the potential future of water rights being decoupled from land rights and the ability to sell water as a commodity. The wine industry is seen as a possible beneficiary of a transition to water markets due to its perceived economic wealth, although the ability to access water in this way would vary greatly within the wine industry as well. A State Water Resources Manager put it this way:
"Well, I think in the places where they have installed water markets and water has become a commodity that it only exacerbates any kind of inequality and accessibility issues in any kind of community. Water is life, and if you don't have water, you don't live."

The future of water policy and management is connected to the social dynamics and fabric of the Willamette Valley wine region, including the sense of community identity and the shifting trends of economics, politics, and values. A researcher of water policy in Oregon shared her opinion about water markets:

"I worry about the commodification of water in that the ones with the money get the water. I'm afraid too many people only understand the value of water, clean and otherwise, in dollars and cents."

Climate change was an important consideration to our interviewees for their understanding of the potential future ecological dynamics of the Willamette Valley wine region's agroecosystems. All Oregon interview participants acknowledged that climate change is happening and it is going to affect the wine industry in the Willamette Valley. Certain risks arise in the region where historically wine grapes have not been irrigated beyond 1 to 2 years to establish new plants. With projected increases in temperature and more frequent heat waves and droughts in summer months, irrigation could become more common and access to irrigation water may become an important consideration in the Willamette Valley wine industry. A viticulturist from California whose company had recently purchased a vineyard in the Willamette Valley shared that he had engaged a climate modeling consultant to generate site specific future climate scenarios, with the main goal of understanding what their water and irrigation needs will be going forward in a wine grape dominated agricultural ecosystem. A viticulture researcher based in Oregon explained that there is still a big learning curve about irrigation needs and outcomes when it comes to Willamette Valley soils. A warmer climate can affect what type of grape varieties can be grown in the region. Pinot noir and cool climate-suited white grapes are predominantly what is currently planted in the Willamette Valley. A number of producers observed that at present, growers in Oregon are not considering planting new varieties of grapevines, but rather there is a shift toward a more technical approach to farming the existing Pinot noir grapes. One vineyard owner argued that climate change mitigation is still essential and can be achieved through farming practices that sequester carbon in the soil. The ecological dynamics created by interactions of intra- and interannual variation in temperature and precipitation, soil types, and the water needs of different grape varieties are an increasing consideration for individual decision making within the region.

\section{Oregon Vignette: Establishing a Vineyard in a Willamette Valley "Critical Groundwater Area"}

The story of J.'s farm brings to light the institutional, social, and ecological limitations individual grape farmers can encounter at the farm scale when trying to adapt the livelihood to changing conditions. J.'s story connects to long term regional 
water needs, and highlights the disconnect between county planning departments and the state water resources department. J.'s story also illustrates the kind of creative yet costly workarounds farmers come up with in the face of water scarcity and institutional constraints. In recent years J. and his wife bought their rural property in a wine grape growing region in the central Willamette Valley. J. had owned and farmed a successful vineyard for over two decades in the north part of the region and when they sold it the couple decided on the new venture further south. The area is home to many high-quality vineyards, and J. knew the new property held lots of potential. He would plant grape vines- Pinot noir, Chardonnay, and Riesling, plus he was enthusiastic to begin a new project-a cider apple orchard. The house on the site had been there for a few decades and had a residential use well-established. J.'s plan was to drill a new well for irrigation which requires a permit from the OWRD. When J. went to the OWRD office to talk with the Watermaster he learned his property fell within a "Critical Groundwater Area," in which means no new uses were allowed. J. petitioned the OWRD for a temporary 5-year permit to use groundwater to irrigate his trees and establish his vineyard. After an 8 month wait, he learned his permit application was denied. J. found out he would not be allowed any water for commercial purposes. He raised the issue with the Watermaster, pointing out that he is a farmer and that new grapevines and apple trees need water. According to J., the Watermaster responded that it was not their problem, and that OWRD was not in charge of zoning, which was the purview of the county. J. approached the county, but they responded that they don't regulate water. As J. puts it: "So you're stuck between two agencies that simply won't communicate about it."

J.'s property is on a county road at the top of a ridge in a predominantly agricultural area. However, in recent years, the county has allowed a number of five-acre residential lots to be developed on this road. Under OWRD rules residential lots are allowed 5,000 gallons per day of unrestricted water for domestic use. Access to water on the ridge is mainly through groundwater wells, and typical to the region, the aquifers on this ridge are perched basalt, where many layers of prehistoric lava flows are interspersed with layers of loose volcanic rubble and ash that limit the formation of large and consistent groundwater aquifers (Oregon State University, 2020). When J. spoke with his neighbors, he realized he was not the only one with water issues in the area. The OWRD rules allow a property owner to pump water from one aquifer only, and, due to cost, most people drill wells into the first, most shallow aquifer. A few neighbors on the road told stories of noticeable reduction of water in their wells in recent years, corresponding to the increased development on the road. One neighbor who has owned his property for 4 years was "playing by the rules" according to J. and drilled his domestic well into the first aquifer, but 2 of the 4 years his well went dry. As J. puts it: "There is proof positive we have a problem...already." J. indicated that it appears the aquifer is over tapped, but the OWRD does not have the resources to study the issue or the authority to regulate further development. According to a researcher at Oregon State University:
"We scientists know very little about groundwater. The groundwater models are really early. They're getting better, but it is not totally clear. I mean, we might say, yeah, there's an aquifer or there's groundwater, but we're not clear about the amount."

J. raised the disconnect between the ORWD rules and the local use of the land, which is driven by county zoning rules. During our interviews this disconnect came up from multiple perspectives, including local elected officials, employees of the OWRD, representatives of environmental conservation organizations, and academic researchers. J.'s perspective on the issues reflects the challenges created by entrenched institutions like OWRD and county zoning rules, the social dynamics caused by development pressure, and a complex ecological system that creates a variable playing field on which individual and collective decision making occurs:

\begin{abstract}
"We feel it's imperative that the county and the water resources board get together about any development. I don't care if it's a house that has to access a domestic well or it's a winery or it's a vineyard. We all have to play by the same rules, and they need to be applied evenly over whomever is doing the development. It's unreasonable to say that everyone who got here first gets all the water. That's nuts. I think what we've got is a broken system that is being supported by law... it doesn't make sense in the face of looking at the future. If we are really going to solve our issues of water going forward, we've got to get away from these artificial boundaries. Water doesn't know property boundaries... water works in basins and drainages. That's how we need to start. We need to start by addressing our water problems in our drainage basin. We need to be assessing what our long-term needs are."
\end{abstract}

Upon learning that he would not get access to groundwater, J. decided on a new approach to adapt to his surrounding conditions. He was permitted to take water from the roof, which is an exempt use in Oregon. J. designed a closed-loop system where he could capture water and generate energy. At considerable cost, J. purchased eight large cisterns from a company in California and installed them at a high point on his property. While visiting the farm, we observed a storage pond under construction at a low point. J. plans to capture rain water from the roofs of buildings and use gravity to pipe the water to the storage pond. The pipe will be fitted with a turbine to capture the energy from the flow. The pipe turbine, and with a small wind turbine will allow J. to pump the water up hill to the holding tanks where it can then will be used for irrigation and operations.

\section{Tasmania, Australia}

The growth of the Tasmanian wine industry is connected to a variety of institutional, social, and ecological dynamics, like outside investment, climate change considerations, and the high value of wine grapes on the island. These dynamics create an economic imperative to transition lower value agricultural uses into higher value crops like grapevines and have favored the development of the Tasmanian wine industry in recent years. Government agencies assist the wine industry in expanding through institutions like enterprise mapping projects, where 
public resources are employed to map soil types, potential irrigation schemes, and climate change projections, which can be overlaid and assessed for suitable grape growing parcels. Social and ecological dynamics, such as the access to capital and regional differences in land suitability, then have a big influence on who can participate in this transition by investing in land with water rights, connecting to water infrastructure, and developing new vineyards in prime water locations.

In Tasmania, as in most of Australia and in contrast to Oregon's Willamette Valley, nearly all vineyards are irrigated during the growing season, and substantial irrigation investments have increased production and growth of the economy of Tasmania. State agencies such as TasWater, Tasmanian Irrigation (TI), Hydro Tasmania, and the Department of Primary Industries, Parks, Water and Environment (DPIPWE) all play a role in fostering the growing wine industry through local water management schemes that support irrigation. TasWater, a jointly owned regional and state government entity, is primarily responsible for developing and managing drinking water and wastewater management on the island, but also plays a role in irrigation (TasWater, 2020). TI is a government-business enterprise that works directly with farmers to design, build, and maintain irrigation schemes in various regions around the eastern drier side of the island (Tasmanian Irrigation, 2020). Under TI irrigation schemes a large amount of water is moved from the wetter parts of the island to the drier areas, which has significantly altered the value of agricultural areas with new access to irrigation. These schemes serve TI's goal to double irrigation capacity within 10 years, which aligns with a broader Tasmanian state policy objective to grow the value of agriculture 10-fold by 2050 (DPIPWE, 2020). Water trading also exists in Tasmania at the local and regional scale within a basin or irrigation scheme, but water markets are not yet formalized at the state level. Some DPIPWE staff are eager to increase the capacity of water markets as an institutional force to help balance the needs of a growing population and agricultural expansion. Farmers, agency managers, and academics we spoke with all agreed that the institutional dynamics of water governance in Tasmania have resulted in the planting of more water intensive crops, and the expansion of the Tasmanian wine industry.

In correspondence with the institutional dynamics, and similar to our findings in Oregon, the social dynamics of the Tasmanian wine industry are also changing as the industry has experienced recent consolidation and outside investment. The favor of the institutional landscape to outside corporate investment has led to a shift toward commodity wine grape production as some larger companies grow and press the grapes in Tasmania, and ship juice in tanker trucks on the ferry to the mainland to be made into wine at existing facilities. The "Race to Tassie" has brought large corporations and investment groups into Tasmania, including big industry names like Treasury Wine Estates, Brown Family Wine Group, Yalumba, Accolade Wines, Hill Smith, Fogarty Wine Group, and Kreglinger. These larger companies have the resources to invest in irrigation schemes, pay for water infrastructure, and buy water on the water market if necessary. Despite the institutional forces to develop the wine industry, this trend shifts the social dynamics of Tasmanian wine away from its traditional identity as a locally made product most often sold on the island to local consumers and visitors. Smaller producers have limited access to the new institutional landscape due to financial constraints, and these constraints are perhaps most visible by the value of a vineyard relative to its proximity to irrigation schemes. One winery owner discussed his recent decision to purchase more vineyard land:

\begin{abstract}
"Water...seasons don't seem to be getting wetter, they seem to be getting drier, and water security in Australia in general-and Tasmania is not exempt from that-is a very important thing... We purchased a property up the road about $20 \mathrm{~km}$ and part of the value of that property is its 100 megaliter water rights, which came with the land. Without that water right it would be almost worthless to us, so it adds huge value to the land."
\end{abstract}

Ecological dynamics drive differences in where irrigation schemes are located and how reliable they are, causing freshwater availability to vary across geographic regions within Tasmania. When asked about water availability in Tasmania, many interviewees were quick to point out that the island has lots of water, it just tends to not be in the place they need it. To address the geographic and ecological disparities in water, irrigation schemes managed by TI, under source agreements with Hydro Tasmania or TasWater, have benefited some regions. In other areas, private recycled water programs have emerged to address water needs. These schemes transport processed residential and commercial wastewater to agricultural areas via pipes and pumps and are typically managed by private companies licensed under TasWater. However, some of the recycled water schemes have had challenges due to salt intrusion. Currently, $\sim 30$ percent of the state has conditions where evaporation exceeds rainfall in most months, causing incoming salt in rainfall to accumulate in the soil or groundwater instead of being washed out. Some irrigation systems can exacerbate soil salinization, and a number of recycled water systems have been shut off as a result. Despite the lack of reliability, interviewees noted significant interest in developing new recycled water projects, particularly in the most heavily populated areas in and around Hobart.

Institutional support for irrigation schemes and ecological differences in water availability have placed a monetary value on water, causing a shift in the social dynamics of water for many Tasmanian farmers, who previously paid nothing for water. Many interviewees anticipate the cost of water will rise as costs to maintain infrastructure persist and further segment farming into those with access and those without. As one water researcher explained:

"People are farming on properties where their father, grandfather,
great grandfather always just extracted. No one asked how much...
people weren't farming so intensively, so people weren't stressing.
But now you have all these rules and different players. It's becoming
far more intensive. It's driving an increase in use even from people
who traditionally didn't need it."

These dynamics also result in different social attitudes about government involvement in water management. In areas where water availability remains scarce, there is a desire by many for 
more government oversight to ensure availability and address fairness of access. In regions where water is more available many farmers are lobbying for more localized community selfregulation of their irrigation schemes. According to one farmer:

"We would run it better than they (TI) would. We're in touch with what's going on day to day so we can defuse problems a lot quicker than they can, before they escalate. We know the individual crops in the district and what needs what and can manage water delivery to those individual needs a lot more efficiently than they can."

\section{Tasmania Vignette: East Coast Struggles: Oversight, Corporate Influence, and Conflict}

The east coast of Tasmania is a grape growing region that has experienced firsthand the shifting institutional, social, and ecological dynamics of water management. The east coast TI irrigation scheme filled quickly with participants including many vineyard owners. Significant costs were paid up front by farmers to construct the scheme, but a number of years have passed and there has yet to be reliable availability of water. Given its location far from the wet western mountains, and far from the large rivers in the central part of the island, this scheme is reliant on rainfall to increase flow in a small river to the point where managers are permitted to fill the reservoir, but the rain had not materialized. When asked what type of planning was being done for the future if rain doesn't fall, one producer's response was direct: there is no other plan. Elaborating on the current institutional hold on the irrigation scheme, she stated:

"It will stay on hold until we get enough water to fill a 3,000 megaliter dam. And then hopefully we will have enough water in it to get us through two seasons. And then hopefully it will rain."

The east coast subregion is a smaller wine region, but it receives a very large number of visitors every year. The drive from the island's major city of Hobart is only $2 \mathrm{~h}$ and visitors find beaches, small coastal towns, and a very popular national park. The east coast is sparsely populated with year-round residents, and like much of the agricultural areas on the island it is a sheep grazing region. According to residents the population balloons from 600 to 5,000 in the summer. The region is very dry and has been experiencing drought conditions for a number of years. The east coast is highly vulnerable to bushfires, and climate conditions have put pressure on the health of coastal and intertidal ecosystems. Water concerns are high on the agenda for both residents and farmers on the east coast. Friction exists between local input to decision making about water and state level oversight. An elected council along with local mayors and natural resource managers negotiates water needs between farmers, residents, businesses, tourism, and the natural environment all in the context of serious water shortages. However, during dry periods DPIPWE commonly issues orders to curtail water use causing community conflict, as some residents, politicians, and local government employees perceive a lack of transparency and communication from the state agency, and a lack of state level involvement with local efforts to address the region's changing water needs.
While visiting the east coast, the lead author attended a meeting of the elected council's Natural Resource Committee, which was made up of natural resource managers, elected councilors, local farmers, grazers, oyster farmers, bushfire officials, and others. Stakeholders discussed the challenges facing water managers in the area and the need to look at the carrying capacity of water resources for tourism. The friction noted by many interviewees for this project was evident as some participants noted that state politicians heavily promote tourism for state economic benefits causing demand for water to increase substantially on the east coast in the summer. In contrast, a community representative commented that the problem was "too many vineyards," while a council member suggested that adaptation was needed and that "water restrictions should be part of our culture." Some expressed the belief that DPIPWE gives large corporate entities that boost the state economy and cater to tourism special access to emergency water allocations from rivers with low flows in the area, while local residents and small farmers are negatively impacted by water overconsumption and access restrictions. "Water management" according to one councilor "equals a black hole."

The story of east coast vineyard owners C. and R.'s experience in recent years illustrates some of the local institutional, social, and ecological challenges that have arisen in the region. C. and $\mathrm{R}$. bought a small vineyard that was originally planted in the 1960s, the first in the area. The couple then bought the neighboring property and expanded their vineyard plantings. C. and $\mathrm{R}$. farm the grapes themselves, along with part time help from their university-age son. Water is needed in the vineyards for irrigation, but also to mitigate damaging spring frosts that are typical to the area. Overhead sprinklers are used for frost mitigation and drip irrigation is used for watering vines. To gain access to water, $\mathrm{C}$. and $\mathrm{R}$. invested in a new dam on their property, paid for a pump and pipes, and bought into the east coast irrigation scheme, which, at the time of our interview, was still not online due to lack of rain. As a backup plan the couple intended to buy water from their neighbor who has a larger dam. C. and R. maintain a home and have converted a barn into tasting room on their vineyard property. During our visit, C. received a text message from DPIPWE on his cell phone, an automated message that informed him they would have to limit pumping from the river due to low flows. The lead author's visit was in the early summer; and the couple did not expect rain to replenish the river flow until late fall, if then. C. shared frustration that the message instructed him to pump 2 of the 7 days in the week, but did not offer details on how much he could pump during those 2 days. Currently any water he pumped directly from the river is unmetered since DPIPWE only requires metering from irrigation schemes. The couple were concerned that overpumping will worsen the shortage, and local growers on the east coast have begun to ask DPIPWE for more oversight and a new requirement that everyone meter their water use. C. and R. expressed that even though it is a close community, there is a bit of an "I've got to protect my patch" attitude, instead of collaborating to try to benefit all. The couple remain very concerned about water and are unsure of the long-term sustainability of grape farming in the area, especially for local farmers. 


\section{ANALYSIS}

The case studies and vignettes provide examples of the interactions between institutional, social, and ecological systems in two wine regions. In the case of the Willamette Valley, entrenched legal regimes and fragmentation of authority are highlighted as barriers for water access (Berry et al., 2006; Arnold, 2014). In the case of J.'s farm, lack of communication and misalignment between state-level water resource management and county-level planning and development processes impacted water availability and access. In Tasmania, an increase in state government oversight regarding water management, led to conflict among those accustomed to less regulation. One challenge facing all policymaking institutions is the need to make decisions about water while often lacking data, science, and information. Both Tasmania and Oregon are hindered by a lack of institutional resources that would allow for adequate staffing and funding for research and data collection. Without the full picture of water availability, current water use, and projected future water needs, institutional decision makers have to act with blinders. In the Willamette Valley this became apparent when overallocation of groundwater rights resulted in water shortages; while at the same time entrenched legal regimes resulted in an unevenness in who can access water. Lack of resources, and potentially a lack of political will, is also credited for challenges with enforcement of current water rules. As the climate changes and as water demands rise, the wine industries continue to grow despite potential longer-term constraints (Mote et al., 2019). Those within the wine industry have a range of attitudes and approaches to water resource and climate change planning (see Table 3). Based on our findings about the interrelationships among the social, institutional, and ecological systems in the case study wine regions, we discuss the barriers to more adaptive solutions and highlight some of the opportunities identified by the interviewees and by us to overcome the barriers.

\section{Barrier: Top-Down Governance Structure}

Both the Willamette Valley and Tasmania have top-down structures of governance for water resources which allows for "big-picture" state-wide decision making about water, but also results in a barrier for local and individual engagement (Arnold, 2014). In Tasmania, state management of water, combined with federal money and legislation, has resulted in technological and engineering approaches to water resource adaptation in the form of irrigation schemes in place of conservation or mitigation strategies. Management of irrigation schemes by the state-level, government-business enterprise, Tasmanian Irrigation, resulted in concerns about the lack of local decision making and transparency about financial costs to farmers. In the Willamette Valley top-down water governance also resulted in a lack of local control or participation in water decisions. One vineyard owner shared his experience in submitting a water use application to the state water department, followed by months of waiting to learn the outcome: "It's a big black box to us... it's just a large regulatory agency, so we put our applications in and we just wait. You learn to be very patient." In top-down governance structures, entrenched legal regimes, like legislation, regulation, and litigation (Arnold, 2004), can be challenging for adaptive management in the face of uncertainty like climate change, and change is a long-term endeavor.

\section{Barrier: Fragmentation of Authority}

The cross-jurisdictional boundary reality of water management in both wine regions, combined with the fragmentation of authority (Bierbaum et al., 2013), can contribute to negative outcomes for water access and water quality. Fragmentation of authority refers to different agencies and levels of government responsible for water quality, water quantity, planning, and development. In Oregon and Tasmania, challenges arise around coordinating policies and reconciling missions, mandates, and timelines. Various entities represent the needs and desires of different interests groups, and interests are not always reconcilable. An example of fragmented authority in the Willamette Valley can be found in J.'s narrative. The conflict arises when the county planning department approves residential or commercial development without consideration of available water resources, because that authority lies with the state water resources department. In Tasmania, a conflict arises between the interests of two authorities, for example, when the local council on the east coast of the island struggles with lack of water availability and prolonged drought, yet the state government, motivated by economic outcomes, encourages an influx of water users in summer months through the promotion of tourism. These examples highlight some of the challenges of addressing climate change adaptation when coupled with the complexity of government, which Urwin and Jordan (2008) describe as a lack of clear definition about institutional roles, responsibilities, and the best scale to address problems.

\section{Barrier: Lack of Resources}

The lack of financial and human resources and political will, can contribute to barriers to climate change adaptation outcomes (Moser and Ekstrom, 2010). In both regions, under-resourced government agencies have resulted in lapses in the collection of scientific data regarding water resources, which impacts the ability for informed decision making about management by those with regulatory oversight. In the Willamette Valley limited resources have resulted in the lack of data collection about ground water availability, resulting in the overallocation of use permits, which has resulted in water shortages for agriculture and residential water users. According to a water department manager, under resourcing may not be neutral, but an attempt by some interest groups, including agriculture lobby groups, to maintain the status quo of water access and use. In Tasmania, one could argue that, in the absence of a wellresourced government, water resource control and management was "outsourced," as described by Lane (2003), to for-profit government-business enterprises, in this case Tasmania Hydro and Tasmanian Irrigation. In the face of limited financial and human resources, both regions have experienced challenges with monitoring and oversight of regulation enforcement regarding illegal water takings and pollution abuses. 
TABLE 3 | Wine industry water resource adaptation actions.

Description Barriers Opportunities

\section{Mitigation}

Reduce greenhouse gas emissions to slow climate change, including carbon sequestering farming practices; changes in energy sourcing and consumption; purchasing carbon offsets.

\section{Increase water use}

Maintain current level of production in farming and winery operations; increase crop yields; expand winery operations; plant new vineyards; build new wineries; increase tourism infrastructure like tasting rooms, accommodations, and dining infrastructure.
Institutional barriers include fragmentation of authority and entrenched legal regimes. Social barriers include necessity to change farming or production operations; costs.
Engage with boundary organizations for education and voluntary financial incentive programs.

3. Reduce water dependency through changes to viticulture options, farming techniques, and/or cellar operations

\section{a. Regenerative viticulture and whole-systems management approach}

Use farming approaches that reduce dependency on added water without need for technological or synthetic inputs. Promoting production and farming methods that focus on sustaining ecological and human health and sustainable economics, but not continuous economic growth.

b. Maintain status quo for current vineyard and cellar production outcomes

Maintain current vineyard crop and production outcomes through a variety of actions including: selection of clones and rootstock; site selection; use viticulture research to increase understanding of vines and soil conditions; buy in to irrigation schemes (Tasmania).

\section{c. Technological approaches}

Using technological approaches, for example soil moisture sensors, recycled water schemes, efficiency technology for irrigation or cleaning in the cellar.

\section{Engage in institutional change}

Could include political involvement, membership in lobbying organizations, grassroots organizing, or stakeholder coalition-building to: institute or expand water markets; limit development to reduce demand for resources; re-allocation of water appropriation; promote policy for water conservation; advocate for improved ecological outcomes.
Lack of widespread knowledge about this farming approaches; mismatch with social value of using water as an economic driver to promote business growth.

Cost; lack of resources for funding or distribution of research findings; geographic and financial barriers to participating in irrigation schemes.

Upfront costs; lack of resiliency if technology fails or becomes outdated/obsolete.

Fragmentation of authority; lack of resources to engage; entrenched legal regimes; potential for maladaptive adaptation promoting the resilience of some systems over others, for example, water markets could lead to water speculation or monopolies of control.
Long term cost savings; engage with boundary organizations for education and voluntary financial incentive programs; increase resiliency by reducing reliance on technology or outside inputs like synthetic chemicals or imported water.

Engage with boundary organizations for education and access regarding latest research findings; look to other wine regions for adaptation strategies in the face of different climate conditions.

Increased efficiencies can result in long term cost savings; positive ecological conservation outcomes (for example, recycled water schemes).

Engage with boundary organizations; participate in a multi-disciplinary/multi-institutional group; influence systemic change that could benefit the wine industry and the public good; influence long term thinking for long term challenges like climate change.

\section{Barrier: Equity Issues and the Potential for Maladaptive Adaptation Outcomes}

As Arnold (2014) described, some institutional decisions can promote the resilience of certain systems while having maladaptive outcomes for others. In the context of social systems in Tasmania, where water is considered an "economic good," and federal and state agencies, along with government-business enterprises, promote water markets to allow users to buy, sell, and trade water as a commodity, there is the risk of increasing inequity in accessing water. Interviewees in Tasmania expressed concern over the potential for water license speculation, and control of water access ending up in the hands "of the highest bidder." Employees of the water resource department for the state of Oregon, along with water lawyers and researchers, shared the view that water markets are likely the future of water access for Oregon and the Willamette Valley. Water markets could move forward, in the context of the prior-appropriation where most water rights are already allocated, resulting in water right holders gaining the option to sell or lease their water to others who have the ability to pay. Other equity issues that arise when considering water access in wine regions are the ability to afford to buy land with associated water rights, or the ability to invest in water storage infrastructure. In Tasmania some maladaptive adaptation outcomes negatively impacted ecological systems, one example being increased soil salinity connected to an irrigation scheme in the Coal River Valley wine region.

\section{Opportunities for Water Resource Focused Climate Change Adaptation}

There are a number of clear and sometimes conflicting approaches to adaptation, some realized and others potential, that are being made by individual farmers to address water needs and climate change in wine regions. One adaptation approach is to increase water use, this may mean increasing irrigation 
because of reduction in precipitation; increased spraying for pests, molds, or mildews brought on by changes to the climate; increased use of water for mitigating extreme heat or frost in the vineyard; or for cellar or hospitality operations in the context of an increase in sales or tourism. A second adaptation approach is to reduce dependency on water through changes in farming approaches, such as implementing techniques like cover cropping to retain soil moisture; or changing viticulture decisions, such as selecting drought tolerant cultivars or choosing heat tolerant grape varieties. A third approach is to focus on mitigation through reduction of greenhouse gas emissions, which can be achieved through changes to farming and wine production operations like a switch to renewable energy in the cellar, or using no-till practices in the vineyard to sequester carbon in the soil. And finally, those in the wine industry can engage in institutional change through political or community activism, serving on advisory boards, or participating in education and outreach efforts to inform policy decisions.

\section{Recommendations \\ Multi-Disciplinary/Multi-Institutional Approach to Tackle Complex Problems}

Collaborative efforts to include a diverse range of stakeholder voices is one opportunity to address complex problems like water resources and climate change. For example, the Oregon Water Resources Department has put forth a goal to form a "nexus" of water governance that brings together considerations for land use planning, infrastructure, permitting, field research, environmental health, public health, and funding (Oregon Water Resources Department, 2018). Local engagement and local planning is an opportunity to build capacity in communities to work with state and federal agencies, while ensuring local goals and values are sustained. In one example in Yamhill County in the Willamette Valley, an elected county commissioner has convened a multi-stakeholder group to consider long range planning for water in their region. In a grassroots effort, irrigators in a sub-region of Tasmania successfully lobbied their state political leaders to address citizen concerns about loss of local control of irrigation schemes and other issues with the state level government-business enterprise in charge of irrigation infrastructure and management. These types of efforts align with Sabatier (1988) public policy research regarding advocacy coalition frameworks, where groups of people from different sectors, not merely government agencies, interest groups, and legislative committees, but also researchers, policy analysts, and journalists, come together to generate and evaluate policy ideas (Jenkins-Smith and Sabatier, 1994).

\section{Engagement With Boundary Organizations}

One opportunity to improve relationships between social systems and institutional systems is to engage and enhance the role of boundary organizations. Boundary organizations refers to collaborative efforts to engage at the intersection of policy and science, often with the goal of the joint construction of knowledge, and informing decision making and policy outcomes (Guston, 2001; Van den Hove, 2007). Boundary organizations, which can include non-governmental organizations, research initiatives, or universities, among others, could be useful for communicating science, conducting outreach, and educating policymakers, politicians, and wine industry producers. An example of boundary organization engagement in wine regions is the non-profit organization based in Portland, Oregon called Salmon Safe. Salmon Safe partners with the agriculture sector, including the wine industry, on a certified eco-label program for agricultural products. In this case Salmon Safe has a peer-reviewed accreditation program that ensures agricultural and manufacturing practices protect watershed health, and in exchange companies can use labels for promotional purposes (Salmon Safe, 2020).

\section{Redistribution of Water Rights}

In both Oregon and Tasmania there was mention in interviews with water managers, grape farmers, and water researchers about the need to consider changing the legislation that allows those with historic or senior water rights to use the most water. The interviewees questioned the fairness and equity of the current laws. Both regions are experiencing a growing need for water for expanding residential populations, critical wildlife habitat, and the demands of agriculture and industry; at the same time, climate change is projected to reduce water availability. In the Willamette Valley, the prior appropriation doctrine of "first in time, first in right," results in unevenness in who can access water in the region and who will have their water use restricted during times of shortage. In Tasmania, historic water rights holders are exempt from certain water use restrictions, creating conflict among neighbors during droughts. Although the need to address the redistribution of water rights was discussed by interviewees in government, research, and the wine industry, it would likely be a slow process due to entrenched legal regimes and stakeholder opposition. The slow timing of the process could be a mismatch with the urgency of climate change risks.

\section{Outreach, Education, and Incentives}

One finding of our research was that many individual grape farmers and vineyard owners do not engage with issues of water governance in their regions beyond their personal situation, and many are not considering long term planning for climate change challenges. One opportunity to expand the level of engagement within the industry is through outreach, education, or incentives. An example in Tasmania is the Australia's Wine Future project, which was jointly funded by the wine industry and the government. For this project researchers created models to determine regional-scale climate change scenarios through 2100 , and worked with industry stakeholders to tailor outcomes expressly for their needs. The project resulted in an online atlas that stakeholders can access to understand specific climate trends for growing conditions in their sub-region in Tasmania which can inform short and long term planning decisions (Harris et al., 2019). Another education-related adaptation opportunity for wine regions is to consider their future climate scenarios, then look to other wine regions currently experiencing those conditions in order to learn from their adaptation strategies. For example, if Tasmania's future climate includes more frequent summer rainfall, they can look to Australia's Hunter Valley wine 
region in New South Wales, where these climatic conditions have been experienced and adapted to for decades (Harris et al., 2019).

\section{Engage in Institutional Change}

At the individual or wine industry level, there is the opportunity to engage in institutional change to impact climate change adaptation outcomes. This engagement could include political involvement through running for office or supporting particular candidates in elections, membership in lobbying organizations, grassroots organizing, or stakeholder coalition-building, which could influence the creation or expansion of water markets; limits to residential, commercial or agricultural development to reduce demand for water resources; re-allocation of water rights; promotion of policy for water conservation; or advocacy for improved ecological outcomes. Industry lobbying organizations do exist in both regions, with the Oregon Wine Board advocating at the state level for the Willamette Valley wine industry, and the industry groups Wine Tasmania and Wine Australia operating with similar missions for the Tasmanian wine industry.

\section{Mitigation}

While a number of strategies to deal with climate change have shifted focus from mitigation to adaptation, the Intergovernmental Panel on Climate Change emphasizes that both mitigation and adaptation are essential for climate change risk management. Mitigation slows the rate and magnitude of climate change, allowing for enhanced capacity to plan for and manage risk (Denton et al., 2014). The wine industry has the ability to reduce greenhouse gas emissions to slow climate change through actions like carbon-sequestering farming practices, changes in energy sourcing and consumption, and purchasing carbon offsets. Regenerative agriculture promotes carbon sequestration through no-till practices, the planting of cover crops, and restoration planting on vineyard properties. These farming practices, called "carbon farming," sequester and store carbon in the soil and in the plants instead of releasing it into the atmosphere (Montgomery, 2017). One example of mitigation efforts in the Willamette Valley is a program created by the Oregon Wine Board, the "Carbon Neutral Challenge," which provides information, support, and incentives for participating wineries.

\section{Potential Limitations}

The research focuses on two specific regions and therefore is not fully representative of the wine industry, environmental context, or institutional characteristics of other grape growing regions. We selected two regions that have important similarities regarding wine industry characteristics and climate challenges, but differences in water governance. These cases can provide lessons applicable to all regions, but further research will be necessary to expand the body of knowledge to specific contexts of other grape growing regions. Further, not all institutional, social, or ecological dynamics were considered, and there may be important dynamics that were omitted. Instead, we focused on the institutional, social, and ecological dynamics highlighted in our interviews. Conducting interviews with a select number of regional knowledge holders does not provide all possible perspectives and insights, but rather a representative selection.

\section{Key Findings}

In Oregon, the main findings that emerge from the ISED synthesis and analysis of our data were: (1) climate change will result in challenges around water resources in the Willamette Valley; (2) current water governance in the region is topdown and that lacks resources for oversight and scientific investigations; (3) entrenched legal regimes, like the prior appropriation doctrine, make changes to water governance challenging and contribute to an unevenness in stakeholder access to water; (4) stakeholder conflict about access to water resources is a current challenge that will grow in the context of a hotter, drier climate with population and wine industry growth; (5) the combination of entrenched legal regimes and an increase in water demand will likely result in a future of water rights shifting to a commodity market system; (6) those within the wine industry have a range of attitudes and approaches to water resource and climate change planning and management; and (7) there are a variety of tactics for climate adaptation around water for the wine industry, but they are dependent on economic resources and social values related to sustainable farming, winemaking, and hospitality operations.

The main findings that emerge in Tasmania from the ISED synthesis and analysis were: (1) climate change will result in challenges around water resources in Tasmania, but the challenges vary based on geographic location on the island; (2) current water governance in the region is a top-down structure that includes federal and state funding and mandates; (3) water is valued as a commodity that can increase economic growth on the island, which has resulted in the intensification of irrigation scheme development; (4) lack of government resources and a political focus on economic growth has transitioned water management to a for-profit, government-business enterprise model; (5) climate and reputation are contributing to an influx of wine industry investment from larger companies on the mainland of Australia; and (6) those within the wine industry have a range of attitudes and approaches to climate change planning and management, but the importance of water is undisputed.

\section{Discussion}

Climate change adaptation in the wine industry is a multidisciplinary problem that requires multidisciplinary solutions, and there is a need to strengthen the interface between scientific remedies and local governance (Howden et al., 2007; Hannah et al., 2013). Our research adds to the broader climate change discourse in wine regions by going beyond viticulture and technological solutions (Hannah et al., 2013; Mozell and Thach, 2014). By examining governance and decision making about water resources in wine regions, we develop a deeper understanding of the influences of social and institutional systems in climate change adaptation, which is useful for adaptation strategies to be successful and durable (Lereboullet et al., 2013). This research contributes 
to the larger body of wine research by incorporating systems thinking, i.e., the ISED framework, into analysis and application. Using this approach, viticulture and enology research can be situated within the larger context of social and natural systems. Understanding drivers that influence decision making capacity can contribute to site-scale outcomes. For example, if viticulture research finds that grapevines would benefit from an increase in irrigation during drought years (Quiggin et al., 2010; Fraga et al., 2018), then a greater understanding of who can access new water rights, or what environmental regulations must be considered, can contribute to adaptation planning.

This study contributes to existing literature that elevates the value of qualitative methods in deepening understanding about attitudes, beliefs, and approaches to climate change adaptation (Moser and Ekstrom, 2010; Engle et al., 2014; Fedele et al., 2019); as well as the barriers and opportunities encountered in water governance (Arnold, 2014; Dunham et al., 2018). Qualitative social science approaches have been used in the context of sustainable agriculture research (Rasmussen et al., 2018; Gosnell et al., 2019) and climate change adaptation research (Moser and Ekstrom, 2010), but are relatively uncommon in wine research, which focuses predominantly on viticulture and enology (for example, the American Journal of Enology and Viticulture or the Australian Journal of Grape and Wine Research) and wine business and economics (for example, the International Journal of Wine Business Research). There is a growing conversation about the relevance and urgency of climate change adaptation for wine regions globally (Cardell et al., 2019; Harris et al., 2019), and qualitative research methods, such as case studies and thematic analysis, can be used to increase understanding about water governance and climate change adaptation. These approaches can also be used to deepen understanding about the relationship between social and natural systems in other aspects of the wine industry, for example, land use, labor issues, and wildfire risk (Martín-López et al., 2017; Palaiologou et al., 2019).

\section{Conclusions}

Currently, in both the Willamette Valley and Tasmanian wine regions, the dominant climate change conversation is focused on planting different grape varieties adapted to warm climates, increasing irrigation, and planting vineyards in new sites with suitable future climate conditions. Our research contributes new understanding of the importance of considering how relationships between institutional, social, and ecological systems influence climate change adaptation choices for individual landowners. The ISED framework proved useful in organizing and structuring the themes that emerged from interviews. The framework accommodated analysis aimed at understanding both the complexity of systems and their relationships. One example of this analysis can be found in the Tasmanian case: Tasmanian Irrigation is an institution created by federal policy and funding, but also resulting from social values equating water with economic growth. Tasmanian Irrigation greatly influences climate change adaptation outcomes for the wine industry, but these outcomes are dependent on the relationship between the social and institutional systems. Ecological systems are also crucial in this example. As suggested by the vignette "East Coast Struggles: Oversight, Corporate Influence, and Conflict," some of the Tasmanian Irrigation schemes will not succeed as local ecosystems may not support water needs under future climate. The ISED framework assisted our understanding of the relationships within and between the institutional, social, and ecological systems.

Our research shares insights and considerations from a diversity of perspectives that provide valuable information for decision making by individual farmers, other stakeholders within the wine industry, natural resource managers, and policymakers in the selected regions and beyond. Our research confirms previous findings from the climate adaptation literature (e.g., Moser and Ekstrom, 2010; Bierbaum et al., 2013) and is a first application of these ideas to current discourse in the wine industry, elevating the understanding of institutional, social, and ecological dynamics within wine region climate adaptation. Our observations and analyses also test the utility of the ISED framework in the context of climate change and water governance, using the framework to determine barriers and opportunities for adaptation. In the agricultural wine region context, the wine industry exists as part of a community and region where water resource interests are shared by numerous stakeholders engaged in immediate and long-term regional dynamics that affect climate adaptation and planning. Our research demonstrates the value of qualitative case studies and thematic analysis using the ISED framework to increase understanding and inform individual and regional decision making. This approach may be useful in the context of other global wine regions grappling with climate change and water resources, as well as other issues such as land use or fire risk where a more complex understanding institutional, social, and ecological dynamics may be useful.

\section{DATA AVAILABILITY STATEMENT}

The datasets presented in this article are not readily available because interview transcripts have not been anonymized and are not available for public release according to our IRB protocol. Requests to access the datasets should be directed to eupton@pdx.edu.

\section{ETHICS STATEMENT}

The studies involving human participants were reviewed and approved by Research Integrity/Institutional Review Board Portland State University. Written informed consent for participation was not required for this study in accordance with the national legislation and the institutional requirements. 


\section{AUTHOR CONTRIBUTIONS}

EU designed and carried out the study, conducted analysis, and wrote and edited the manuscript. MN-P contributed ideas, reviewed and verified methods and analysis, and co-wrote and edited the manuscript. All authors contributed to the article and approved the submitted version.

\section{FUNDING}

This material was based on work supported by National Science Foundation IGERT Grant \#0966376: Sustaining Ecosystem Services to Support Rapidly Urbanizing Areas, and the Oregon

\section{REFERENCES}

Antarctic Climate and Ecosystems Cooperative Research Centre (2010). Climate Futures for Tasmania Extreme Events: The Summary. Hobart, TAS: ACE CRC.

Arnold, C. (2004). Working out an environmental ethic: anniversary lessons from Mono Lake. Wyoming Law Rev. 4, 1-55. Available online at: https://papers. ssrn.com/sol3/papers.cfm?abstract_id=1025857 (accessed January 5, 2017).

Arnold, C. A. (2014). Social-ecological resilience of an eastern urbansuburban watershed: the anacostia river basin. Idaho Law Rev. 51:29. doi: 10.2139/ssrn.2584968

Arnold, C. A., Gosnell, H., Benson, M. H., and Craig, R. K. (2017). Crossinterdisciplinary insights into adaptive governance and resilience. Ecol. Soc. 22:14. doi: 10.5751/ES-09734-220414

Ascough Ii, J. C., Maier, H. R., Ravalico, J. K., and Strudley, M. W. (2008). Future research challenges for incorporation of uncertainty in environmental and ecological decision-making. Ecol. Modell. 219, 383-399. doi: 10.1016/j.ecolmodel.2008.07.015

Atkinson, R., and Flint, J. (2004). "Snowball sampling," in The SAGE Encyclopedia of Social Science Research Methods, Vol. 1, eds M. S. Lewis-Beck, A. Bryman, and T. F. Liao (Thousand Oaks, CA: SAGE Publications, Inc), 1044-1044.

Belliveau, S., Smit, B., and Bradshaw, B. (2006). Multiple exposures and dynamic vulnerability: evidence from the grape industry in the Okanagan Valley, Canada. Glob. Environ. Change 16, 364-378. doi: 10.1016/j.gloenvcha.2006.03.003

Bennett, J. C., Ling, F. L. N., Graham, B., Grose, M. R., Corney, S. P., White, C. J., et al. (2010). Climate Futures for Tasmania: Water and Catchments Technical Report. Hobart: Antarctic Climate and Ecosystems Cooperative Research Centre.

Berkes, F., Colding, J., and Folke, C. (eds.). (2008). Navigating Social-Ecological Systems: Building Resilience for Complexity and Change. Cambridge: Cambridge University Press.

Berry, P. M., Rounsevell, M. D. A., Harrison, P. A., and Audsley, E. (2006). Assessing the vulnerability of agricultural land use and species to climate change and the role of policy in facilitating adaptation. Environ. Sci. Policy 9 , 189-204. doi: 10.1016/j.envsci.2005.11.004

Bierbaum, R., Smith, J. B., Lee, A., Blair, M., Carter, L., Chapin, F. S., et al. (2013). Mitigation and Adaptation Strategies for Global Change 18. Berlin: Springer Verlag, 361-406.

Braun, V., and Clarke, V. (2006). Using thematic analysis in psychology. Qual. Res. Psychol. 3, 77-101. doi: 10.1191/1478088706qp063oa

Cardell, M. F., Amengual, A., and Romero, R. (2019). Future effects of climate change on the suitability of wine grape production across Europe. Reg. Environ. Change 19, 2299-2310. doi: 10.1007/s10113-01901502-x

Comandaru, I. M., Barjoveanu, G., Peiu, N., Ene, S. A., and Teodosiu, C. (2012). Life cycle assessment of wine: focus on water use impact assessment. Environ. Eng. Manag. J. 11, 533-543. doi: 10.30638/eemj.2012.066
Sasakawa Young Leaders' Fellowship Fund of the Tokyo Foundation for Policy Research.

\section{ACKNOWLEDGMENTS}

We wish to share our appreciation of the welcoming attitudes and helpful conversations with Dr. Rebecca Harris and Dr. Tom Remenyi of the University of Tasmania; as well as the guidance and support for this project from Dr. Jeremy Spoon, Dr. Vivek Shandas, and Dr. Daniel Jaffee of Portland State University. We are also grateful to the two reviewers whose suggestions and critiques helped improve the manuscript.
Conradie, A., Sigge, G. O., and Cloete, T. E. (2014). Influence of winemaking practices on the characteristics of winery wastewater and water usage of wineries. South Afr. J. Enol. Viticult. 35, 10-19. doi: 10.21548/35-1-981

Deitch, M. J., Kondolf, G. M., and Merenlender, A. M. (2009). Hydrologic impacts of small-scale instream diversions for frost and heat protection in the California wine country. River Res. Appl. 25, 118-134. doi: 10.1002/rra.1100

Denton, F., Wilbanks, T., Abeysinghe, A., Burton, I., Gao, Q., Lemos, M., et al. (2014): "Climate-resilient pathways: adaptation, mitigation, and sustainable development," in Climate Change 2014: Impacts, Adaptation, and Vulnerability. Part A: Global and Sectoral Aspects. Contribution of Working Group II to the Fifth Assessment Report of the Intergovernmental Panel on Climate Change, eds C. B. Field, V. R. Barros, D. J. Dokken, K. J. Mach, M. D. Mastrandrea, T. E. Bilir, M. Chatterjee, K. L. Ebi, Y. O. Estrada, R. C. Genova, B. Girma, E. S. Kissel, A. N. Levy, S. MacCracken, P. R. Mastrandrea, and L. L. White (Cambridge and New York, NY: Cambridge University Press), 1101-1131.

Denzin, N. K., and Lincoln, Y. S. (eds.). (2011). The Sage Handbook of Qualitative Research. New York, NY: Sage.

DEQ (2009). Willamette Basin Rivers and Streams Assessment. Portland, OR: Oregon Department of Environmental Quality. Available online at: https:// www.oregon.gov/deq/FilterDocs/DEQ09-LAB-016.pdf (accessed September 21, 2019).

DPIPWE (2020). Tasmanian Government Department of Primary Industries Parks Water and Environment. Water Quality Monitoring- Parameters. Available online at: https://dpipwe.tas.gov.au/water/water-monitoring-and-assessment/ water-monitoring/surface-water-quality/water-parameters (accessed February 03, 2019).

Dunham, J., Angermeier, P., Crausbay, S., Cravens, A., Gosnell, H., McEvoy, J., et al. (2018). Rivers are social-ecological systems: time to integrate human dimensions into riverscape ecology and management. WIREs Water 2018:e1291. doi: 10.1002/wat2.1291

Ecos (2013). Australian Wine Producers Lead Climate Change Adaptation. Available online at: Ecos.com (accessed March 07, 2016).

Engle, N. L., de Bremond, A., Malone, E. L., and Moss, R. H. (2014). Towards a resilience indicator framework for making climate-change adaptation decisions. Mitig. Adapt. Strateg. Glob. Change 19, 1295-1312. doi: $10.1007 / \mathrm{s} 11027-013-9475-\mathrm{x}$

Fedele, G., Donatti, C. I., Harvey, C. A., Hannah, L., and Hole, D. G. (2019). Transformative adaptation to climate change for sustainable social-ecological systems. Environ. Sci. Policy 101, 116-125. doi: 10.1016/j.envsci.2019.07.001

Forbes, S. L., Cullen, R., and Grout, R. (2013). Adoption of environmental innovations: analysis from the Waipara wine industry. Wine Econ. Policy 2, 11-18. doi: 10.1016/j.wep.2013.02.001

Fox-Hughes, P., Harris, R. M. B., Lee, G., Jabour, J., Grose, M. R., Remenyi, T. A., et al. (2015). Climate Futures for Tasmania Future Fire Danger: The Summary and the Technical Report. Hobart: Antarctic Climate \& Ecosystems Cooperative Research Centre. 
Fraga, H., de Cortázar Atauri, I. G., and Santos, J. A. (2018). Viticultural irrigation demands under climate change scenarios in Portugal. Agric. Water Manag. 196, 66-74. doi: 10.1016/j.agwat.2017.10.023

Furer, D. (2006). Why the Wine Industry Should Care About Global Warming? Wine Business. Available online at: https://www.winebusiness.com/wbm/?go= getArticleSignInanddataId=43868 (accessed March 07, 2016).

Gosnell, H., Gill, N., and Voyer, M. (2019). Transformational adaptation on the farm: processes of change and persistence in transitions to "climate-smart" regenerative agriculture. Glob. Environ. Change 59:101965. doi: 10.1016/j.gloenvcha.2019.101965

Guston, D. H. (2001). Boundary organizations in environmental policy and science: an introduction. Sci. Technol. Hum. Values 26, 399-408. doi: $10.1177 / 016224390102600401$

Hadarits, M., Smit, B., and Diaz, H. (2010). Adaptation in viticulture: a case study of producers in the Maule region of Chile. J. Wine Res. 21, 167-178. doi: 10.1080/09571264.2010.530109

Hannah, L., Roehrdanz, P. R., Ikegami, M., Shepard, A. V., Shaw, M. R., Tabor, G., et al. (2013). Climate change, wine, and conservation. Proc. Natl. Acad. Sci.U.S.A. 110, 6907-6912. doi: 10.1073/pnas.1210127110

Harris, R. M. B., Remenyi, T. A., Hayman, P., Thomas, D., Risbey, J., Petrie, P., et al. (2019). AUSTRALIA'S WINE FUTURE: Adapting to Short-Term Climate Variability and Long-Term Climate Change. Final Report to Wine Australia, Antarctic Climate and Ecosystems Cooperative Research Centre, University of Tasmania.

Holling, C. S., and Gunderson, L. H. (2002). "Resilience and adaptive cycles," in Panarchy: Understanding Transformations in Human and Natural Systems, eds L. H. Gunderson and C. S. Holling (Washington, DC: Island Press), 25-62.

Howden, S. M., Soussana, J. F., Tubiello, F. N., Chhetri, N., Dunlop, M., and Meinke, H. (2007). Adapting agriculture to climate change. Proc. Natl. Acad. Sci. U.S.A. 104, 19691-19696. doi: 10.1073/pnas.0701890104

Jaeger, W. K., Plantinga, A. J., Chang, H., Dello, K., Grant, G., Hulse, D., et al. (2013). Toward a formal definition of water scarcity in naturalhuman systems, Water Resour. Res. 49, 4506-4517. doi: 10.1002/wrcr. 20249

Jenkins-Smith, H. C., and Sabatier, P. A. (1994). Evaluating the advocacy coalition framework. J. Public Policy 14, 175-203. doi: 10.1017/S0143814X000 07431

Jimenez Cisneros, B. E., Oki. T., Arnell, N. W., Benito, G., Cogley, J. G., Dall, P., et al. (2014). "Freshwater resources," in Climate Change 2014: Impacts, Adaptation, and Vulnerability. Part A: Global and Sectoral Aspects. Contribution of Working Group II to the Fifth Assessment Report of the Intergovernmental Panel on Climate Change, eds C. B. Field, V. R. Barros, D. J. Dokken, K. J. Mach, M. D. Mastrandrea, T. E. Bilir, M. Chatterjee, K. L. Ebi, Y. O. Estrada, R. C. Genova, B. Girma, E. S. Kissel, A. N. Levy, S. MacCracken, P. R. Mastrandrea, and L. L.White (Cambridge and New York, NY: Cambridge University Press), 229-269.

Jones, G. V., and Webb, L. B. (2010). Climate change, viticulture, and wine: challenges and opportunities. J. Wine Res. 21, 103-106. doi: 10.1080/09571264.2010.530091

Jones, G. V., White, M. A., Cooper, O. R., and Storchmann, K. (2005). Climate change and global wine quality. Clim. Change 73, 319-343. doi: $10.1007 /$ s10584-005-4704-2

Kay, J. (2006, July 11). Now's the time to cellar wine/Scientists fear/Scientists fear that rising temperatures due to global warming will harm the wine industry in Napa, Sonoma, and Santa Barbara counties. San Francisco Chronicle, News/Politics. Available online at: https://www.sfgate.com/politics/ article/Now-s-the-time-to-cellar-wine-Scientists-fear-2493071.php (accessed March 23, 2017).

Lane, M. B. (2003). Decentralization or privatization of environmental governance? forest conflict and bioregional assessment in Australia. J. Rural Stud. 19, 283-294. doi: 10.1016/S0743-0167(02)00084-0

Lange, B., and Shepheard, M. (2014). Changing conceptions of rights to water? an eco- socio-legal perspective. J. Environ. Law 26, 215-242. doi: $10.1093 / \mathrm{jel} / \mathrm{equ} 013$

Lereboullet, A. L., Beltrando, G., and Bardsley, D. K. (2013). Socio-ecological adaptation to climate change: a comparative case study from the Mediterranean wine industry in France and Australia. Agric. Ecosyst. Environ. 164, 273-285. doi: 10.1016/j.agee.2012.10.008
Lewis, G. K., Byrom, J., and Grimmer, M. (2015). Collaborative marketing in a premium wine region: the role of horizontal networks. Int. J. Wine Bus. Res. 27, 203-219. doi: 10.1108/IJWBR-06-2014-0028

Martín-López, B., Palomo, I., García-Llorente, M., Iniesta-Arandia, I., Castro, A. J., Del Amo, D. G., et al. (2017). Delineating boundaries of social-ecological systems for landscape planning: A comprehensive spatial approach. Land Use Policy. 66, 90-104. doi: 10.1016/j.landusepol.2017.04.040

Montgomery, D. R. (2017). Growing a Revolution: Bringing Our Soil Back to Life. WW Norton \& Company.

Moser, S. C., and Ekstrom, J. A. (2010). A framework to diagnose barriers to climate change adaptation. Proc. Natl. Acad. Sci. U.S.A. 107, 22026-22031. doi: 10.1073/pnas.1007887107

Mote, P. W., Abatzoglou, J., Dello, K. D., Hegewisch, K., and, Rupp, D. E. (2019). Fourth Oregon Climate Assessment Report. Oregon Climate Change Research Institute. Available online at: occri.net/ocar4 (accessed October 07, 2019).

Mozell, M. R., and Thach, L. (2014). The impact of climate change on the global wine industry: challenges and solutions. Wine Econ. Policy 3, 81-89. doi: 10.1016/j.wep.2014.08.001

OIV (2019). Statistical Report on World Vitiviniculture. Paris: International Organisation of Vine and Wine Intergovernmental Organisation. Available online at: http://www.oiv.int/public/medias/6782/oiv-2019-statistical-reporton-world-vitiviniculture.pdf (accessed February 15, 2020).

Oregon State University (2020). Willamette Water 2100 Project Overview. Available online at: https://inr.oregonstate.edu/ww2100/about/projectoverview (accessed February 15, 2020).

Oregon Water Resources Department (2018). Water Rights In Oregon, An Introduction to Oregon's Water Laws. Available online at: https://www.oregon. gov/owrd/WRDPublications1/aquabook.pdf (accessed February 15, 2020).

Oregon Wine Board (2019). 2019 Oregon Winery Visitor Profile Study Report. Available online at: https://industry.oregonwine.org/resources/reportsstudies/2019-oregon-winery-visitor-profile-study-report/ (accessed February $15,2020)$.

Ostrom, E. (2009). A general framework for analyzing sustainability of social-ecological systems. Science 325, 419-422. doi: 10.1126/science.11 72133

Palaiologou, P., Ager, A. A., Nielsen-Pincus, M., Evers, C. R., and Day, M. A. (2019). Social vulnerability to large wildfires in the western USA. Landsc. Urban Plan. 189, 99-116. doi: 10.1016/j.landurbplan.2019.04.006

Patton, M. Q. (1990). Qualitative Evaluation and Research Methods, 2nd Edn. New York, NY: Sage.

Porter, J. R., Xie, L., Challinor, A. J., Cochrane, K., Howden, S. M., Iqbal, M. M., et al. (2014). "Food security and food production systems," in Climate Change 2014: Impacts, Adaptation, and Vulnerability. Part A: Global and Sectoral Aspects. Contribution of Working Group II to the Fifth Assessment Report of the Intergovernmental Panel on Climate Change, eds C. B. Field, V. R. Barros, D. J. Dokken, K. J. Mach, M. D. Mastrandrea, T. E. Bilir, M. Chatterjee, K. L. Ebi, Y. O. Estrada, R. C. Genova, B. Girma, E. S. Kissel, A. N. Levy, S. MacCracken, P. R. Mastrandrea, and L. L.White (Cambridge and New York, NY: Cambridge University Press), 485-533.

Quiggin, J., Adamson, D., Chambers, S., and Schrobback, P. (2010). Climate change, uncertainty, and adaptation: the case of irrigated agriculture in the Murray-Darling Basin in Australia. Canad. J. Agric. Econ. 58, 531-554. doi: 10.22004/ag.econ.152096

Rasmussen, L. V., Coolsaet, B., Martin, A., Mertz, O., Pascual, U., Corbera, E., et al. (2018). Social-ecological outcomes of agricultural intensification. Nat. Sustain. 1, 275-282. doi: 10.1038/s41893-018-0070-8

Redman, C., Grove, M. J., and Kuby, L. (2004). Integrating Social Science into the Long Term Ecological Research (LTER) network: social dimensions of ecological change and ecological dimensions of social change. Ecosystems 7, 161-171. doi: 10.1007/s10021-003-0215-z

Sabatier, P. (1988). An advocacy coalition framework of policy change and the role of policy-oriented learning therein. Policy Sci. 21, 129-68. doi: 10.1007/BF00136406

Salmon Safe (2020). Available online at: https://salmonsafe.org/about/ (accessed March 17, 2020).

Tasmanian Irrigation (2020). Available online at: https://www.tasmanianirrigation. com.au/about-tasmanian-irrigation (accessed March 17, 2020). 
TasWater (2020). About Us/Who Is TasWater. Available online at: https://www. taswater.com.au/About-Us/Who-is-TasWater- (accessed March 17, 2020).

Tate, A. B. (2001). Global warming's impact on wine. J. Wine Res. 12, 95-109. doi: 10.1080/09571260120095012

Upton, E., and Nielsen-Pincus, M. (2020). “Addressing social outcomes in land and water management for global wine regions," in Social Sustainability in the Global Wine Industry (Cham: Palgrave Pivot), 155-167.

Urwin, K., and Jordan, A. (2008). Does public policy support or undermine climate change adaptation? exploring policy interplay across different scales of governance. Glob. Environ. Change 18, 180-191. doi: 10.1016/j.gloenvcha.2007.08.002

Van den Hove, S. (2007). A rationale for science-policy interfaces. Futures, 39, 807-826. doi: 10.1016/j.futures.2006.12.004

White, M. A., Whalen, P., and Jones, G. V. (2009). Land and wine. Nat. Geosci. 2:82. doi: $10.1038 /$ ngeo 429

Willamette Valley Wineries Association (2020). About the Valley. Available online at: https://willamettewines.com/about-the-valley/

Wine Tasmania (2020). Available online at: http://winetasmania.com.au/ (accessed March 17, 2020).
Winemakers Federation of Australia (2013). Wine industry report: expert report on the profitability and dynamics of the Australian wine industry. Report prepared for Winemakers Federation of Australia by Centaurus Partners. Available online at: www.wfa.org.au/assets/noticeboard/Expert-Review-Report.pdf (accessed March 17, 2020).

Winetitles (2010). The Australian and New Zealand Wine Industry Directory, 28th Edn, Broadview, SA: Winetitles.

Conflict of Interest: The authors declare that the research was conducted in the absence of any commercial or financial relationships that could be construed as a potential conflict of interest.

Copyright (C) 2021 Upton and Nielsen-Pincus. This is an open-access article distributed under the terms of the Creative Commons Attribution License (CC BY). The use, distribution or reproduction in other forums is permitted, provided the original author(s) and the copyright owner(s) are credited and that the original publication in this journal is cited, in accordance with accepted academic practice. No use, distribution or reproduction is permitted which does not comply with these terms. 
Appendix 1 | Main (Parent) Codes for Comparative Case Study Interview Data.

1. Attitudes and Perceptions

2. Climate Adaptation

3. Climate Change

4. Decision Making

5. Government Regulatory Body

6. Economics/Money

7. Environmental Concerns

8. Government Business Enterprise

9. Irrigation

10. Legislation/Regulatory Frameworks

11. Oversight
12. Policy \& Management Plans

13. Political Will

14. Power \& Influence

15. Private Property Considerations

16. Relationships/Communication

17. Research

18. Sharing Information or Data

19. Transformation

20. Water

21. Weather/Climate Variability

22. Wine Industry 